\title{
Linguodidactica KKIIII
}

DOI: 10.15290/lingdid.2019.23.01

\author{
dr hab. Elżbieta Bogdanowicz \\ Uniwersytet w Białymstoku \\ Wydział Filologiczny, Katedra Językoznawstwa Slawistycznego \\ tel. (85) 7457450 \\ e-mail: e.bogdanowicz@uwb.edu.pl \\ ORCID ID: https://orcid.org/0000-0002-8675-6815
}

\section{NAZWISKA JAKO ŚWIADECTWO WIELOKULTUROWOŚCI PODLASIA}

\begin{abstract}
ABSTRAKT
Niniejszy artykuł dotyczy regionalnej antroponimii. Jego przedmiot stanowiq genetycznie zróżnicowane nazwiska, identyfikujące przedstawicieli grup etnicznych zamieszkujących Podlasie, które potwierdzaja wielokulturowy charakter regionu. Pochodzenie podlaskich nazwisk ustalono na podstawie cech leksykalnych, fonetycznych, słowotwórczych i innych, co pozwoliło wyodrębnić nazwiska o genezie polskiej, wschodniosłowiańskiej, litewskiej oraz niemieckiej, a także nazwy osobowe Żydów i Tatarów. Jako specyfikę tego etnicznie niejednorodnego zasobu antroponimów wskazano formacje hybrydalne, łączące w jednej strukturze różne elementy językowe.
\end{abstract}

Słowa kluczowe: Podlasie, wielokulturowość, onomastyka, antroponimia regionalna, nazwisko

\section{ABSTRACT}

\section{SURNAMES AS A TESTIMONY TO THE MULTICULTURALISM OF PODLASIE}

This paper is concerned with regional anthroponymy. Its subject refers to genetically diverse surnames, which identify representatives of ethnic groups living in borderland Podlasie and confirm the multicultural character of this region. The origin of Podlasie surnames was established on the basis of lexical, phonetic, word forming and other features that allowed the identification of surnames of Polish, East Slavic, Lithuanian and German origin, as well as personal names of Jews and Tartars. Specific features of this set of anthroponyms are indicated, such as hybrid formations that combine various linguistic elements in one structure.

Key words: Podlasie, multiculturalism, onomastics, regional anthroponymy, surname 


\section{Wprowadzenie}

Wielokulturowość, rozumiana jako współwystępowanie wielu kultur, ma ścisły związek z usytuowanym na polsko-ruskim pograniczu Podlasiem, będącym obszarem stykania się kilku etnosów i kultur: polskiego, litewskiego, białoruskiego, ukraińskiego, tatarskiego, żydowskiego, niemieckiego. Zróżnicowanie etniczno-kulturowe omawianego terenu to przede wszystkim rezultat zmian przynależności administracyjnej i politycznej, odgrywania roli strefy granicznej między Polską, Litwą, Rusią oraz przebiegu procesu osadnictwa ${ }^{1}$.

Intensywne kolonizowanie Podlasia rozpoczęło się pod koniec $X$ wieku. Od zachodu napływali osadnicy polscy (mazowieccy), zajmując dorzecze górnej Narwi i część ziem nad Bugiem². W tym czasie nad dopływami górnej Biebrzy i nad Niemnem utrzymywała się jeszcze ludność bałtycka (litewska i jaćwieska), coraz bardziej wypierana przez Mazowszan, a także od wschodu - przez Rusinów, głównie pochodzenia wołyńskiego ${ }^{3}$. Kolonizatorzy ruscy najgęściej zaludniali ziemie nad Bugiem, słabiej nad Narwią i jej południowymi dopływami. Wiek XIII to okres zgodnej koegzystencji ludności polskiej i ruskiej na ziemiach podlaskich, ale graniczne położenie Podlasia powodowało, że przez kilka następnych stuleci było ono obszarem nieustannych walk i prób przyłączenia w drodze podboju i kolonizacji do krajów ościennych. Terytorium Podlasia należało kolejno do Rusi, Litwy, Polski, a od XVIII wieku przejściowo do Prus, Rosji, Polski, ZSRR, Niemiec oraz ponownie Polski ${ }^{4}$. Zmiany przynależności państwowej determinowały kierunki i natężenie migracji, doprowadzając w konsekwencji do podziału Podlasia na trzy główne obszary etniczne: 1) polski (zachodni), podlegający w przeszłości silnej polskiej ekspansji z Mazowsza, 2) ukraiński (południowo-wschodni), zasiedlony przez ludność ruską, przybyłą z północnej Ukrainy oraz 3) białoruski (północno-wschodni), zajęty przez białoruskich kolonizatorów znad Niemna i Rosji z dużą domieszką ludności litewskiej5. Dodatkowo strukturę narodowościową na Podlasiu wzbogaciło osadnictwo tatarskie, a także silne - zwłaszcza

1 M. Barwiński, Podlasie jako region pogranicza, „Studia z Geografii Politycznej i Historycznej” 2014, t. 3, s. 281-282.

2 Atlas gwar wschodniosłowiańskich Białostocczyzny (reedycja), S. Glinka, A. Obrębska-Jabłońska, J. Siatkowski (red.), t. 1, Warszawa 2014, s. 14.

3 Ibidem.

4 M. Barwiński, Wplyw granic oraz uwarunkowań politycznych na zmiany struktury narodowościowej $i$ wyznaniowej na przykładzie Podlasia, [w:] Czas i przestrzeń w naukach geograficznych. Wybrane problemy geografii historycznej, M. Kulesza (red.), Łódź 2008, s. 49.

5 Atlas gwar wschodniostowiańskich..., s. 26. 
w XVII wieku - osadnictwo żydowskie ${ }^{6}$. Skutkiem rządów pruskich na badanym terenie, przypadających na lata 1795-1807, było krótkotrwałe pojawienie się kolonistów niemieckich, których większość po 1815 roku przeniosła się do Prus Wschodnich 7 .

Z odmiennością etniczną osadników wiązały się różnice religijne: Mazowszanie byli rzymskimi katolikami, Rusini wyznawali prawosławie. Aktywność na omawianym terytorium wykazywali także muzułmańscy Tatarzy, żydowscy wyznawcy judaizmu oraz kolonizatorzy niemieccy - zwolennicy kilku kierunków reformowanych ${ }^{8}$.

Tak więc na pogranicznym Podlasiu na przestrzeni stuleci wykształciła się integralna, ale oparta na niejednorodności etnicznej i religijnej wspólnota kulturowo-komunikatywna, w naturalny sposób generująca różnorodność w obrębie języka, którą w wyrazisty sposób ilustrują polskie, wschodniosłowiańskie, litewskie, niemieckie, żydowskie i tatarskie nazwiska identyfikujące mieszkańców tych ziem, tworzące unikatowy w skali Polski zasób antroponimów.

Nazwiska jako kategorię antroponimiczną cechuje dziedziczność, tzn. zdolność przechodzenia z ojca, niekiedy też z matki na dziecko. Antroponimy te są elementem identyfikującym i integrującym członków danej rodziny, świadczą o ich wspólnych korzeniach oraz łączących więziach9. Współczesne nazwisko odznacza się ustaloną formą językową i wraz z imieniem należy do oficjalnych, urzędowo zatwierdzonych nazw osobowych, ale jednocześnie może być uznane za dokument historyczny o niezwykłych walorach poznawczych i kulturowych, nośnik informacji o wspólnocie zamieszkującej dane terytorium.

Wszystkie te właściwości odnoszą się także do nazwisk funkcjonujących na Podlasiu, co oznacza, że jako źródło historyczne mogą one stanowić kompendium wiedzy o kulturowym obliczu regionu, tożsamości etniczno-religijnej, a także językowej jego mieszkańców.

$Z$ badań onomastów ${ }^{10}$ zajmujących się pograniczem polsko-ruskim wynika, że zaliczane do systemu antroponimicznego Podlasia wszystkie typy nazwisk (zarówno antroponimy niederywowane i morfologicznie derywowane w planie nazwisk, jak i jednostki wyodrębnione na podstawie kryterium gene-

6 A. Wyrobisz, Podlasie w Polsce przedrozbiorowej, [w:] Studia nad społeczeństwem i gospodarka Podlasia w XVI-XVIII wieku, A. Wyrobisz (red.), Warszawa 1981, s. 173-210.

7 Atlas gwar wschodniosłowiańskich..., s. 25.

8 J. Maciszewski, Społeczeństwo, [w:] Polska XVII wieku, Warszawa 1977, s. 130.

9 K. Rymut, Nazwiska Polaków, Kraków 1999, s. 9.

10 Por. liczne prace autorstwa Z. Abramowicz, L. Citko, L. Dacewicz i in., np. L. Citko, Nazewnictwo osobowe pótnocnego Podlasia w XVI w., Białystok 2001; Z. Abramowicz, Antroponimia Żydów białostockich, Białystok 2010; L. Dacewicz, Historia nazwisk na kresach pótnocno-wschodnich Rzeczpospolitej (XVI-XVIII w.), Białystok 2014. 
tyczno-historycznego, uwzględniającego podstawy motywacyjne nazwisk oraz funkcje tworzących je sufiksów słowotwórczych) wykazują różną przynależność kulturowo-językową, którą postaram się w niniejszym opracowaniu zaprezentować.

\section{Nazwiska polskie}

Za nazwiska polskie $\mathrm{z}$ genetycznego punktu widzenia, występujące na badanym terenie, należy uznać antroponimy motywowane polskimi podstawami apelatywnymi lub onimicznymi, które dodatkowo w swych strukturach mogą zawierać rozpowszechnione $\mathrm{w}$ innych regionach Polski, a więc z pewnością typowe dla polskiego nazewnictwa osobowego, słowotwórcze wykładniki formalne. Przegląd wielu opracowań poświęconych antroponimii Podlasia ${ }^{11}$ dostarcza przekonujących dowodów na to, że funkcjonujące tu typy nazwisk powielają podstawowe modele nazewnicze, wyodrębnione przy opisie nazwisk związanych z innymi obszarami Polski ${ }^{12}$. Różnice, świadczące o regionalnej specyfice analizowanych antroponimów, dotyczą frekwencji poszczególnych typów nazwisk oraz produktywności formantów nazwiskotwórczych, a także ilościowego i jakościowego udziału nazwisk o obcej (niepolskiej) proweniencji.

$\mathrm{Na}$ podstawie kryterium semantycznego jako podstawowe typy nazwisk na omawianym terytorium zazwyczaj wskazywane są: 1) miana odapelatywne o charakterze przezwiskowym, w szerokiej formule obejmujące także nazwy wykonywanych zawodów, pełnionych funkcji, piastowanych urzędów, a także nazwy etniczne ${ }^{13}, 2$ ) nazwiska patronimiczne, bazujące głównie na różnorodnych formach imion oraz 3) antroponimy odmiejscowe ${ }^{14}$.

11 Wykaz literatury z zakresu tej problematyki (s. 101-107), zawierający najnowsze opracowania, do artykułu opublikowanego w 18. tomie "Studiów Wschodniosłowiańskich" dołączyła L. Dacewicz (Podlasie w badaniach onomastycznych w przekroju historycznym - stan obecny, zadania i potrzeby, Białystok 2018, s. 89-107).

Zob. np. J. Bubak, Kształtowanie się polskiego nazwiska mieszczańskiego i chłopskiego, Kraków 1986; B. Mossakowska, Nazwiska mieszkańców Komornictwa Olsztyńskiego, Gdańsk 1993; M. Magda-Czekaj, Wybrane typy słowotwórcze nazwisk okresu średniopolskiego w ujęciu historyczno-społecznym, Kraków 2011; A. Sieradzki, Poznańskie derywaty nazwiskowe XVI-XVIII wieku, Poznań 2013.

13 Np. B. Tichoniuk w monografii Antroponimia południowej Białostocczyzny w XVI wieku (Opole 1988, s. 54-99) do antroponimów o przezwiskowym rodowodzie włącza nazwy osobowe odzawodowe i odetniczne.

14 Te właśnie trzy główne typy nazwisk na obszarze Podlasia - czasami z mniejszymi lub większymi modyfikacjami w zakresie tego wyjściowego podziału - wymieniają najczęściej badacze, m.in. Z. Abramowicz, L. Dacewicz, L. Citko, E. Bogdanowicz, M. Mordań. 
Wśród zasobu podlaskich nazwisk jednostki o polskim rodowodzie stanowią dominujący komponent. Powiązania tej grupy antroponimów z systemem języka polskiego zaznaczają się na kilku płaszczyznach: leksykalnej, fonetycznej, strukturalnej i dotyczą podstaw nazwisk oraz formantów sufiksalnych.

W nazwiskach powstałych na bazie wyrazów pospolitych (apelatywów), zarówno w strukturach nazw tożsamych pod względem formy $\mathrm{z}$ apelatywami, jak i w formacjach pochodnych, tzn. motywowanych leksemami pospolitymi, nader często tkwią semantycznie zróżnicowane wyrazy pospolite zaczerpnięte z polszczyzny, np. Balwierz'15 (: ap. balwierz 'golibroda, felczer'), Bałamutko (: ap. batamut 'człowiek zawodny, nierzetelny; gaduła'), Biedzicz (: ap. bieda), Chromy (: ap. chromy 'kulawy, skaleczony, ułomny'), Czajkowicz (: ap. czajka 'gatunek ptaka'), Drążyk (: ap. drag 'długi kij; wysoki człowiek'), Flis (: ap. flis 'szkutnik'), Grzyb (: ap. grzyb), Kolpak (: ap. kotpak 'rodzaj czapki'), Kramarz (: ap. kramarz 'kupiec, drobny handlarz'), Krawczyk (: ap. krawiec), Łysik (: ap. lysy), Marszałek (: ap. marszałek), Mężaj (: ap. męż 'mężczyzna; człowiek odważny, dostojny'), Piskorz (: ap. piskorz 'gatunek ryby'), Postowicz (: ap. post 'częściowe wstrzymanie się od jedzenia'), Radło (: ap. radło 'dawne narzędzie do orania'), Skrzypek (: ap. skrzypek), Srożec (: ap. srogi), Talarowicz (: ap. talar 'jednostka monetarna'), Tkacz (: ap. tkacz), Wrzosek (: ap. wrzos), Zwada (: ap. zwada 'kłótnia, spór') itd.

Warto $\mathrm{w}$ tym miejscu także wspomnieć o niederywowanych i derywowanych mianach, wywodzących się od etnonimów ${ }^{16}$, które - obok podstawowej funkcji neutralnego określania przynależności etnicznej identyfikowanych osób - w niektórych użyciach tekstowych stają się nacechowanymi ekspresywnie przezwiskami (np. Niemiec, Rosjanin, Żyd), niosącymi pewne emocjonalne nadwyżki znaczeniowe ${ }^{17}$. Ta wtórna właściwość nazw etnicznych umożliwia rozpatrywanie ich $\mathrm{w}$ obrębie nazwisk odapelatywnych, $\mathrm{z}$ czego korzystam przy ustalaniu proweniencji (tu: polskiej) użytego podłoża językowego, np. Lachow (: etn. Lach 'Polak'), Litwinek (: etn. Litwin), Mazurek (: etn. Mazur 'mieszkaniec Mazur lub Mazowsza'), Niemiec (: etn. Niemiec), Polak (: etn. Polak), Rusinowicz (: etn. Rusin), Tatarzyn (: etn. Tatarzyn 'Tatar'), Żydziuk (: etn. Żyd) itp.

Jako materiał ilustracyjny przywoływane będą podlaskie nazwiska wyekscerpowane z kilku źródeł: mojej rozprawy doktorskiej pt. XVIII-wieczne nazewnictwo osobowe południowej Białostocczyzny, Białystok 2000 (wydruk komputerowy); Słownika historycznych nazw osobowych Białostocczyzny (XV-XVII w.) Z. Abramowicz, L. Citko, L. Dacewicz t. I-II, Białystok 1997-1998; monografii L. Dacewicz, Historia nazwisk na kresach.... Ze wskazanych opracowań zaczerpnięto też motywacje poszczególnych nazw. Etnonimy to nazwy narodów, narodowości, plemion i innych grup etnicznych.

Na zdolność nazw etnicznych (szczególnie narodowości) do nasycania się treściami znaczeniowymi (konotacyjnymi) w obrębie danej wspólnoty językowo-komunikatywnej zwróciła uwagę K. Pisarkowa, Konotacja semantyczna nazw narodowości, [w:] K. Pisarkowa, Z pragmatycznej stylistyki, semantyki i historii języka. Wybór zagadnień, Kraków 1994, s. 215-234. 
Polską genezę wielu nazwisk na Podlasiu można potwierdzić za pomocą baz imiennych, które w przeważającej mierze tworzą tzw. formacje patronimiczne, identyfikujące ludzi przez wskazanie na jakąś zależność rodzinną. O polskości tego typu nazw osobowych najdobitniej świadczą obecne w ich strukturze pełne, skrócone, deminutywne, hipokorystyczne formy imion chrześcijańskich, należące do systemu imienniczego Kościoła rzymskokatolickiego, np. Andrzejew (: im. Andrzej), Balcer (: im. Balcer $\leftarrow$ Baltazar), Barttomiejczyk (: im. Bartłomiej), Bonik (: im. Bonik $\leftarrow$ Bonifacy), Dominikowicz (: im. Dominik), Frąc (: im. Frąc $\leftarrow$ Franciszek), Filipko (: im. Filip), Florczuk (: im. Florek $\leftarrow$ Florian), Grzesienia (: im. Grześs $\leftarrow$ Grzegorz), Ignaczyk (: im. Ignacy), Irzykowicz (: im. Irzyk $\leftarrow$ Jerzy), Jacko (: im. Jacko $\leftarrow$ Hiacynt), Jakubowicz (: im. Jakub), Janko (: im. Janko $\leftarrow$ Jan), Krzysztofowicz (: im. Krzysztof), Łukaszyk (: im. Łukasz), Maciejkowicz (: im. Maciejko $\leftarrow$ Maciej), Marciszew (: im. Marcisz $\leftarrow$ Marcin), Piotruszyk (: im. Piotrusz $\leftarrow$ Piotr), Szczepanów (: im. Szczepan), Szymkiewicz (: im. Szymek $\leftarrow$ Szymon), Tomczyk (: im. Tomek, Tomko $\leftarrow$ Tomasz), Urban (: im. Urban), Zych (: im. Zych $\leftarrow$ Zygmunt) i wiele innych.

Typowo polskim elementem $\mathrm{w}$ zbiorze omawianych nazwisk są derywaty odtoponimiczne złożone $\mathrm{z}$ nazw miejscowości - najczęściej usytuowanych na terenie Podlasia - i formantu -ski/-cki, np. Białostocki (: n. m. Białystok), Białowieski (: n. m. Białowieża), Chrabołowski (: n. m. Chraboły), Gutowski (: n. m. Guty), Hryniewicki (: n. m. Hryniewicze), Idźkowski (: n. m. Idźki), Kalinowski (: n. m. Kalinowo, Kalinówka), Kryński (: n. m. Krynki), Łapiński (: n. m. Łapy), Michałowski (: n. m. Michałowo), Narewski (: n. m. Narew), Przestrzelski (: n. m. Przestrzele), Rudnicki (: n. m. Rudniki), Sokołowski (: n. m. Sokołów, Sokoły), Wyrozębski (: n. m. Wyrozęby), Zabłudowski (: n. m. Zabłudów) itd. Ten rozpowszechniony tu (i produktywny na obszarze całej Polski) rodzaj mian osobowych świadczy o silnym związku podlaskiej antroponimii z polską kulturą nazewniczą, w której formacje na -ski/-cki (pierwotnie odmiejscowe, ponieważ wynikające z posiadania w określonym miejscu ziemi) już od końca XVI wieku uznawane były za polskie nazwy wzorcowe (modelowe) ${ }^{18} \mathrm{i}$ - jako identyfikatory polskiej szlachty stanowiły nie tylko symbol wyższości społecznej i dobrobytu tej warstwy, ale także kultywowanych przez nią wartości duchowych i obyczajowych ${ }^{19}$. Z tego względu w XVIII wieku na Podlasiu rozpowszechniło się zjawisko dodawania przez mieszczan i chłopów do swoich apelatywnych nazwisk elementu -ski, np. Mikołay Błycha/Błyszynski, Chwedory Szczawuch/Szczawuszyński, co miało

18 Zob. np. S. Gala, Produktywne typy antroponimiczne, „Rozprawy Komisji Językowej ŁTN”, XXXIV, 1978, s. 39-53; S. Rospond, O nazwiskach na -ski, „Poradnik Językowy” 1966, 1, s. 1-12; J. Matuszewski, Polskie nazwisko szlacheckie, Łódź 1975. 
znamionować awans społeczny (przejście do wyższego stanu) przedstawicieli nieszlachty i zapewnić im uprzywilejowaną pozycję w społeczeństwie ${ }^{20}$.

\section{Nazwiska wschodniosłowiańskie (ruskie)}

O pojawieniu się na Podlasiu licznych nazwisk o proweniencji wschodniosłowiańskiej zdecydowało przede wszystkim geograficzne położenie tych ziem, które skutkowało określonym przebiegiem ich zasiedlania. W czasach aktywnej kolonizacji, o czym już wspominano, na tereny Podlasia niemal równorzędnie z Polakami i przynależnym im nazewnictwem wkraczała ludność ruska z antroponimią nasyconą wschodniosłowiańskimi (głównie białoruskimi lub ukraińskimi) elementami językowymi.

Podlaskie nazwiska ruskiego pochodzenia liczebnością dorównują polskim nazwom osobowym. Na tych samych płaszczyznach trzeba też rozważać genetyczną styczność antroponimów ruskich z językami wschodniosłowiańskimi.

W wielu nazwach odapelatywnych istniejących na Podlasiu można wyodrębnić podstawy o proweniencji wschodniosłowiańskiej (chodzi o wyrazy pospolite, które jednakowo brzmią w języku białoruskim, ukraińskim i rosyjskim, tzn. powstały przed podziałem wschodniosłowiańskiej wspólnoty językowej), białoruskiej lub ukraińskiej, np. Alchow (: ap. brus. gw. alcha 'olcha'), Błycha (: ap. brus. błycha 'pchła'), Czmut (: ap. ukr. czmut 'psotnik, kawalarz'), Czupra (: ap. wsł. czupra 'brudas, flejtuch'), Dubotołk (: ap. brus. dubotołk 'ten, który przygotowuje korę dębową do garbowania'), Dudarenia (: ap. wsł. dudar 'grający na dudzie'), Hanczar (: ap. brus. hanczar 'garncarz'), Kaczelewicz (: ap. brus. kaczeli 'huśtawka'), Kuszniruk (: ap. ukr. kusznir 'kuśnierz'), Łastowczyc (: ap. brus. łastouka 'jaskółka'), Połuda (: ap. ukr. połuda 'katarakta, bielmo'), Posoł (: ap. wsł. posoł 'poseł'), Sipacz (: ap. brus. sipacz 'człowiek mówiący ochrypłym głosem'), Sutulik (: ap. wsł. sutułyj 'człowiek przygarbiony'), Szachrun (: ap. ukr. szachrun 'oszust, kanciarz'), Szut (: ap. wsł. szut 'błazen'), Tetera (: ap. ukr. tetera 'cietrzew'), Wereszczaka (: ap. ukr. wereszczaka 'krzykacz'), Wołk (: ap. wsł. wołk 'wilk'), Worobiej (: ap. wsł. worobiej 'wróbel') itd.

Do języków wschodniosłowiańskich odnoszone jest też pochodzenie całego szeregu baz imiennych tworzących nazwiska Podlasian. Imiona te, wywodzące się z kręgu kultury bizantyjskiejej, na omawiany obszar trafiały za pośrednic-

20 E. Bogdanowicz, Proces kształtowania się nazewnictwa osobowego południowej Białostocczyzny, [w:] Studia Slawistyczne 2. Nazwy własne na pograniczach kulturowych, Z. Abramowicz, L. Dacewicz (red.), Białystok 2000, s. 24.

21 L. Citko, Nazewnictwo osobowe północnego..., s. 26. 
twem prawosławnego Kościoła wschodniego i motywują one - wraz z polskimi wersjami fonetycznymi imion chrześcijańskich - największą liczbę podlaskich antroponimów patronimicznych, np. Anfimiuk (: im. cerk. Anfim), Arcichowicz (: im. wsł. Arcich $\leftarrow$ cerk. Artemij), Charko (: im. wsł. Charko $\leftarrow$ cerk. Charyton), Chilimoniuk (: im. wsł. Chilimon $\leftarrow$ cerk. Filimon), Chomacz (: im. wsł. Choma $\leftarrow$ cerk. Foma), Denisko (: im. wsł. Denisko $\leftarrow$ Denis, cerk. Dionisij), Gieniew (: im. wsł. Gień $\leftarrow$ cerk. Jewgienij), Grygorycz (: im. wsł. Grygor $\leftarrow$ cerk. Grigorij), Hawryłow (: im. wsł. Hawryło $\leftarrow$ cerk. Gawriił), Ihnatowicz (: im. wsł. Ihnat $\leftarrow$ cerk. Ignatij), Ilia (: im. cerk. Ilia), Klimiuk (: im. wsł. Klim $\leftarrow$ cerk. Klimientij), Lewonko (: im. wsł. Lewonko $\leftarrow$ cerk. Leont, Leontij), Mikitka (: im. wsł. Mikita $\leftarrow$ cerk. Nikita), Naumik (: im. cerk. Naum), Prokopiew (: im. wsł. Prokop $\leftarrow$ cerk. Prokopij), Panasiuk (: im. wsł. Panas $\leftarrow$ cerk. Afanasij), Sawczuk (: im. wsł. Sawko $\leftarrow$ cerk. Sawwa, Sawielij), Supruniak (: im. wsł. Suprun $\leftarrow$ cerk. Sofronij), Sysycz (: im. wsł. Sysa $\leftarrow$ cerk. Sisoj), Ułasowicz (: im. wsł. Ułas $\leftarrow$ cerk. Własij), Wawruczuk (: im. wsł. Wawruk $\leftarrow$ cerk. Ławrentij), Weremicz (: im. wsł. Weremiej $\leftarrow$ cerk. Jeremija) itp.

Genezę tego czy innego antroponimu w dobitny sposób potwierdzają cechy fonetyczne. W analizowanym zbiorze nazwisk można wyróżnić wiele wschodniosłowiańskich (często typowo białoruskich lub ukraińskich) cech fonetycznych, m.in.: 1) pełnogłos (wsł. realizacja prsł. grup *tort, "*tolt, *tert, *telt), np. Berestiuk, Moroz, Wereszczaka, Wołodkiewicz; 2) szczelinowa, gardłowa spółgłoska $h$ zamiast $g$ (cecha brus. lub ukr.), np. Ihnatowicz, Hawryluk, Horbaczuk, Koczerha; 3) samogłoski ustne zamiast nosowych, $u$ jako kontynuant * $q$ i ' $a$ jako kontynuant ${ }^{*} e$, np. Dubina, Huszcza, Sukaczyk, Zubek; 4) $r$ na miejscu ${ }^{*} r$ ' w pol. $r z$, np. Dudarenia, Jastrab, Prystupa, Rymar; 5) dyspalatalizacja spółgłosek przed dawną samogłoską e (cecha ukr.), np. Berezowicz, Demianiuk, Kapelka, Omelaniuk; 6) dziekanie i ciekanie, czyli zamiana dawnych miękkich spółgłosek ${ }^{*} t^{\prime},{ }^{*} d^{\prime}$ na $c^{\prime}, d z^{\prime}$ (cecha brus.), np. Cierechowicz, Cimochowicz, Dziak, Dziemidko; 7) ikanie (cecha ukr.), np. Biłuha, Kliszcz, Kołodijczuk, Kuszniruk; 8) półmiękka wymowa spółgłosek $d^{\prime}, t^{\prime}$, np. Dawydiuk, Kostiukowicz, Szatiłowicz, Wawdijuk; 9) akanie (cecha brus.), np. Haraczka, Kałbaska; 10) uproszczenie grupy *dl, np. Szyło.

$\mathrm{Na}$ ruskie pochodzenie omawianych nazw osobowych wskazują sufiksy użyte do ich formowania. Niezbity dowód silnych związków tych antroponimów z kulturą wschodniosłowiańską stanowią ogromnie popularne na Podlasiu struktury patronimiczne, które wyrażały preferowaną przez Słowian wschodnich wartość, tzn. uznawanie przez nich za najcenniejsze dobro przynależności do wspólnej rodziny i wspólnego przodka ${ }^{22}$. Nazwiska tego ro- 
dzaju na badanym terenie urabiano za pomocą formantów nazwiskotwórczych -icz/-ewicz/-owicz, -ow/-ów/-ew, -uk/-czuk, -ko, -ik/-yk/-czyk i innych, w większości utożsamianych $z$ antroponimią białoruską i ukraińską. $W$ poszczególnych stuleciach $w$ rozkładzie typów strukturalnych jednostek patronimicznych zachodziły zmiany, np. w XVI wieku najistotniejszą rolę odgrywały formacje wykorzystujące przyrostek -icz/-ewicz/-owicz ${ }^{23}$, na XVIII wiek zaś przypada dominacja sufiksu -uk/-czuk ${ }^{24}$. Formanty patronimiczne mogły łączyć się z podstawami o różnym pochodzeniu, chociaż przewaga baz odimiennych, wynikająca z pierwotnej genezy nazwisk patronimicznych, jest niepodważalna.

Przy opisie nazwisk polskiego i ruskiego pochodzenia, od wieków koegzystujących na terenie Podlasia, należy odnotować fakt występowania pokaźnej liczebnie grupy polsko-wschodniosłowiańskich formacji hybrydalnych ${ }^{25}$, które łączą w jednej strukturze antroponimicznej polskie i wschodniosłowiańskie elementy językowe, np. hybrydami (w kontekście formalno-językowym) są funkcjonujące tu na szeroką skalę nazwiska ze wschodniosłowiańskim wykładnikiem formalnym -uk/-czuk, dodawanym do polskich podstaw słowotwórczych: Andrzejuk, Bernaciuk, Cieśluk, Czyżuk, Doboszuk, Frączuk, Grzebieńczuk, Grzesiuk, Jasiuk, Kleszczuk, Kruczuk, Łopaciuk, Maciejuk, Marczuk, Michalczuk, Szczuruk, Wojtuluk, a także antroponimy z polskim sufiksem -ski/-cki, przyłączanym do wschodniosłowiańskich baz apelatywnych lub imiennych: Błyszeński, Hrybczyński, Kanaszewski, Kołosowski, Kostanecki, Krapicki, Szczawuszyński, Szybiński, Szyryński, Wakuliński. Ta mnogość polsko-wschodniosłowiańskich nazwisk hybrydalnych $\mathrm{w}$ obrębie podlaskich mian osobowych to rezultat zetknięcia się, nakładania się i współoddziaływania na tym obszarze odmiennych, acz pokrewnych języków i wzorców nominacyjnych, prowadzące do naturalnej integracji wschodnio- i zachodniosłowiańskiej kultury nazewniczej. $Z$ tego też powodu większa część badaczy zgłębiających antroponimię na Podlasiu ${ }^{26}$ nie wprowadza ostrego podziału między polskimi i wschodniosłowiańskimi nazwami osobowymi, uznając je za element rodzimy w systemie antroponimicznym regionu.

23 Zob. np. L. Citko, Nazewnictwo osobowe pótnocnego..., s. 65-70.

24

Por. np. L. Dacewicz, Rola sufiksu -uk w kulturze nazewniczej Podlasia, [w:] Manuscula Linguistica in honorem Aleksandrae Cieślikowa oblata, K. Rymut, K. Skowronek, B. Czopek-Kopciuch, M. Malec (red.), Kraków 2006, s. 158; E. Bogdanowicz, Proces kształtowania się nazewnictwa..., s. 24.

O hybrydalnym charakterze nazewnictwa osobowego na pograniczach pisały m.in. L. Citko, Formacje hybrydalne w antroponimii polsko-białorusko-litewskiego pogranicza XVI wieku, [w:] Nazewnictwo pogranicza Polski, A. Belchnerowska, J. Ignatowicz-Skowrońska (red.), Szczecin 1999, s. 43-49; L. Dacewicz, Hybrydyzacja nazewnictwa mniejszości narodowych jako zjawisko typowe na pograniczach etniczno-kulturowych, [w:] Onimizacja i apelatywizacja, Z. Abramowicz, E. Bogdanowicz (red.), Białystok 2006, s. 357-362.

26 Por. np. L. Citko, Nazewnictwo osobowe pótnocnego..., s. 95; L. Dacewicz, Historia nazwisk na kresach..., s. $174-175$. 


\section{Nazwiska litewskie}

Ziemia podlaska od wieków była strefą kontaktowania się Słowian i Bałtów, co znalazło wymierne odzwierciedlenie w niemałej ilości funkcjonujących tu nazwisk pochodzenia litewskiego, zwłaszcza w sferze ich motywacyjnego odniesienia do litewskiego słownictwa apelatywnego, lub litewskich nazw własnych innego zakresu (głównie imion).

Podobnie jak w przypadku słowiańskich struktur antroponimicznych o genezie apelatywnej można wśród podlaskich nazwisk (niederywowanych i derywowanych) wyodrębnić litewskie wyrazy pospolite należące do kilku tematycznie zróżnicowanych grup, np. Brolew (: ap. lit. brolis 'brat'), Dojlid (: ap. lit. dailide 'cieśla'), Giedrow (: ap. lit. gièdras 'bezchmurny'), Gierwa (: ap. lit. gèrvé 'żuraw'), Karstow (: ap. lit. kàrštas 'gorący, żarliwy'), Kiewło (: ap. lit. kiaùle 'świnia'), Kniaba (: ap. lit. knebà, knébe 'z garbatym nosem'), Odega (: ap. lit. uodegà 'ogon'), Padagiel (: ap. lit. padegélis 'pogorzelec'), Pukszta (: ap. lit. pūkšti 'dyszeć, sapać'), Reklo (: ap. lit. rekla 'krzykacz, płaksa'), Sarko (: ap. lit. šárka 'sroka'), Trumpa (: ap. lit. trumpas 'krótki') itd.

Do nielicznych należą patronimiczne formy odimienne mające swe źródło $\mathrm{w}$ imiennictwie litewskim, np. Bottruk $\leftarrow(:$ im. Bottr $\leftarrow$ lit. Baltras, Baltrus, Bołtr $\leftarrow$ lit. Baltras, Baltrus, Baltramiějus), Ginwiło (: im. lit. Ginvilas), Onelis (: im. lit. Anèlius). Większe wyzyskanie baz imiennych w obrębie omawianych nazwisk, co potwierdzają badania L. Citko ${ }^{27}$, dotyczy starolitewskich imion dwuczłonowych, np. Burgiela (: lit. im. złoż. Burgáila, Bargáila), Gasztołd (: lit. im. złoż. Góštautas), Ginwiło (: lit. im. złoż. Gìnvilas), Narbut (: lit. im. złoż. Nórbutas, Nárbutas).

Nazwiska litewskie na Podlasiu - z powodu ścisłego kontaktu z językiem polskim i językami wschodniosłowiańskimi - dość wcześnie uległy slawizacji, a jednym $\mathrm{z}$ jej pierwszych przejawów było dodawanie formantu -icz/-ewicz/-owicz do litewskich podstaw słowotwórczych, bezpośrednio lub za pośrednictwem litewskich sufiksów w funkcji swoistego łącznikaa ${ }^{28}$, np. w antroponimach Dojni-ewicz, Gerw-el-ewicz, Gojdzi-el-ewicz, Kieci-ewicz, Krumi-el-icz, Sznyp-owicz, Ziemojt-owicz, co zapoczątkowało intensywny proces powstawania na tych ziemiach nazwisk o strukturze hybrydalnej - słowiańsko-bałtyckiej.

\footnotetext{
27 L. Citko, Nazewnictwo osobowe pótnocnego..., s. 108.

28 L. Dacewicz, Historia nazwisk na kresach..., s. 193-194.
} 


\section{Nazwiska niemieckie}

Większość nazwisk niemieckich dotarła na omawiane terytorium pod koniec XVIII wieku ${ }^{29}$, i miało to związek z III rozbiorem Polski, w wyniku którego część północną Podlasia wcielono do Prus. Na zaanektowany obszar zaczęli przybywać pruscy wojskowi, urzędnicy oraz rzemieślnicy ${ }^{30}$, wzbogacając obecny tu zasób antroponimów swoimi nazwiskami.

Niemieckie nazwy osobowe na Podlasiu zachowały status obcości, gdyż nigdy nie nastąpiła ich pełna adaptacja do polskiego systemu językowego, np. Denhoff, Edelmann, Hippel, Klein, Korff, Richter, Schmidt. Znamiona minimalnej asymilacji tych antroponimów ograniczają się do poziomu fonetyczno-graficznego ${ }^{31}$, np. Arent $\leftarrow$ niem. Ahrend, Klem $\leftarrow$ niem. Klemm, Metner $\leftarrow$ niem. Metzner, Szulc $\leftarrow$ niem. Schultz, Szuman $\leftarrow$ niem. Schumann.

\section{Nazwiska Żydów}

Ważny komponent obrazu etnicznego Podlasia (zwłaszcza w przeszłości) stanowili Żydzi ${ }^{32}$. Grupa ta, w odróżnieniu od innych mieszkańców regionu, nie wykształciła własnych zasad tworzenia nazwisk i chętnie korzystała ze struktur używanych przez ludność kraju osiedlenia. W przypadku Podlasia polegało to przede wszystkim na powielaniu polskich i ruskich zwyczajów nazewniczych ${ }^{33}$.

W identyfikacji osobowej podlaskich Żydów (ceniących ponad wszystko wartości rodzinne) przeważały miana patronimiczne, a największą frekwencją cieszyły się nazwy czerpiące z żydowskiego zasobu imienniczego - rozpoznawalnego wyznacznika żydowskiej tożsamości - derywowane przy pomocy formantu -ewic(z)/-owic(z), np. Abelowicz ${ }^{34}$ (: im. bibl. Abel), Ajzykowicz (: im. Ajzyk $\leftarrow$ bibl. Icchak, Izaak), Boruchowic (: im. bibl. Baruch), Chackielowicz (: im. Chackiel

29 We wcześniejszych stuleciach nazwiska pochodzenia niemieckiego występowały na ziemi podlaskiej sporadycznie.

30 A. Małek, Białystok pod zaborem pruskim 1795-1807, „Białostocczyzna” 1999, nr 4, s. 19-24.

L. Dacewicz, Historia nazwisk na kresach..., s. 217.

32 Zgodnie z ustaleniami L. Dacewicz (Antroponimia Żydów Podlasia w XVI-XVIII wieku, Białystok 2008, s. 10-29) pierwsi żydowscy osadnicy na ziemiach podlaskich pojawili w drugiej połowie XV wieku, a przez dwa kolejne stulecia trwał ich intensywny napływ. Żydzi osiedlali się głównie w miastach, zachowując odrębność wyznaniową i prawną. W XVIII wieku zwiększenie liczby mieszkańców żydowskiego pochodzenia na Podlasiu to przede wszystkim rezultat przyrostu naturalnego.

33 L. Dacewicz, Antroponimia Żydów Podlasia..., s. 68-95; Z. Abramowicz, Antroponimia Żydów białostockich....

34 Nazwiska identyfikujące przedstawicieli narodu żydowskiego zostały głównie zaczerpnięte z: L. Dacewicz, Antroponimia Żydów Podlasia.... 
$\leftarrow$ bibl. Jechezkiel), Chaimowic (: im. hebr. Chaim), Fiszkowicz (: im. jid. Fiszel), Jankielewicz (: im. Jankiel $\longleftarrow$ bibl. Jakob), Mendlowicz (: im. hebr. Mendel), Moszkiewicz (: im. Moszko $\leftarrow$ bibl. Mosze), Nisonowicz (: im. hebr. Nison, Nisan), Pejsachowicz (: im. bibl. Pejsach, Pesachja), Uszerowicz (: im. hebr. Uszer, Aszer), Szymszonowicz (: im. hebr. Szymszon) itd.

Z innych patronimicznych wykładników nazwiskotwórczych, funkcjonujących na Podlasiu, ludność żydowska korzystała sporadycznie, np. Anzeluk (: im. hebr. Enzel, Anszel), Hercyk (: im. Hercyk $\leftarrow$ jid. Herc), Lejbko (: im. jid. Lejb), Pinkasow (: im. bibl. Pinchas, Pinkas), Szabszyn (: im. bibl. Szabsaj, Szabtaj), Zawelko (: im. Sawel $\leftarrow$ bibl. Saul, Szaul), Zelmanczyk (: im. jid. Zelman).

Rzadko też podlascy Żydzi do tworzenia własnych nazwisk stosowali typowo polski sufiks -ski/-cki, ale jeśli taki fakt miał miejsce, to w antroponimach tych jako podstawy tkwiły nazwy miejscowości położone na terenie całej Polski (nie tylko na Podlasiu) lub poza jej dzisiejszymi granicami, np. Drehlowski, Gdański, Grodzieński, Kalwaryjski, Krakowski; Królewiecki, Poznański, Suraski, Tykociński.

W odniesieniu do odapelatywnych antroponimów identyfikujących Żydów na omawianym obszarze można sformułować uwagę, że są one przejawem interferencji języka polskiego i języków wschodniosłowiańskich ${ }^{35}$. Cechy takiego oddziaływania występują zarówno w nazwach odzawodowych, np. Bakałarz, Cyrulik, Furman, Kramarz, Rabin, Szynkarz, Złotnik, jak i odprzezwiskowych, np. Borodawka, Brechaczek, Czarnomordy, Głupiec, Tołkacz.

\section{Nazwiska Tatarów}

Początki osadnictwa tatarskiego na ziemi podlaskiej to zasługa wielkiego księcia litewskiego Witolda, który osadzał Tatarów na terenach między Narwią i Bugiem już pod koniec XIV wieku ${ }^{36}$.

Ludność pochodzenia tatarskiego pod wpływem swych słowiańskich sąsiadów podlegała dynamicznej adaptacji. To dostosowanie objęło także proces przejmowania przez Tatarów nazwisk charakterystycznych dla polsko-ruskiego pogranicza. W konsekwencji antroponimy identyfikujące społeczność tatarską na Podlasiu, pełniące funkcję nazwisk, nie różnią się od struktur wykorzystywanych przez słowiańskich mieszkańców regionu.

W korpusie nazwisk odnoszących się do mniejszości tatarskiej na Podla-

35

36

L. Dacewicz, Antroponimia Żydów Podlasia..., s. 83-86.

L. Dacewicz, Nazwiska Tatarów w dawnym województwie podlaskim (XVI-XVIII w.), [w:] Nazewnictwo pogranicza Polski, A. Belchnerowska, J. Ignatowicz-Skowrońska (red.), Szczecin 1999, s. 63. 
siu dominują jednostki derywowane na -ewicz/-owicz oraz -ski/-cki. Formacje patronimiczne z sufiksem -ewicz/-owicz dość często motywowane są imionami obowiązującymi wyznawców islamu, np. Ajdarewicz (: im. tat. Ajdar), Alejewicz (: im. tat. Alija), Kasimowicz (: im. arab. Kasim), Mustafowicz (: im. arab. Mustafa), Usejnowicz (: im. muz. Chusejn). W funkcji baz słowotwórczych w tym typie antroponimów rozpowszechnione są też imiona chrześcijańskie.

Podstawy imienne o różnej genezie kryją się w nazwiskach Tatarów z formantem -ski/-cki, np. Mucharski (: im. arab. Mucharem), Olejowski (: im. Olej $\leftarrow$ tat. Alija, Olija), Smolski (: im. Smola $\leftarrow$ arab. Ismail), co należy uznać za cechę specyficzną nazewnictwa osobowego tej grupy etnicznej, gdyż w polskiej antroponimii sufiks -ski/-cki w głównej mierze łączono z nazwami miejscowości.

\section{Podsumowanie}

Procesy nazwiskotwórcze na Podlasiu były skorelowane przede wszystkim $\mathrm{z}$ rozwojem na tym terytorium wieloetnicznego osadnictwa, czyli dogodnej przestrzeni do wzajemnego przenikania różnych kultur i języków, w której mógł uformować się oryginalny, etnicznie niejednolity zbiór nazwisk. Dominującą rolę odegrały $\mathrm{w}$ nim uznawane za rodzime miana pochodzenia polskiego i wschodniosłowiańskiego. Nazwiska litewskie, funkcjonując w otoczeniu języków słowiańskich, ulegały stopniowej slawizacji - głównie polonizacji. $\mathrm{W}$ odniesieniu do podlaskiego systemu antroponimicznego nazwiska niemieckie zachowały swą odrębność. Natomiast nazwy osobowe określające Żydów i Tatarów powielały wykształcone przez ludność polską i ruską wzorce nazewnicze. Z racji wieloetnicznej struktury osadnictwa na Podlasiu w omawianym korpusie nazwisk odnotowano też znaczną liczbę struktur hybrydalnych.

Jak wynika z poczynionych obserwacji, nazwiska są cennym źródłem informacji o języku i kulturze społeczeństwa zamieszkującego dane terytorium, a w przypadku niejednorodnej wspólnoty językowo-komunikatywnej na Podlasiu - o specyfice wielu grup etnicznych.

\section{Rozwinięcia użytych skrótów}

$\begin{array}{llll}\text { ap. } & - \text { apelatyw } & \text { cerk. } & \text { - cerkiewny } \\ \text { arab. } & - \text { arabski } & \text { etn. } & \text { - etnonim } \\ \text { bibl. } & - \text { biblijny } & \text { gw. } & \text { - gwarowy } \\ \text { brus. } & - \text { białoruski } & \text { hebr. } & \text { - hebrajski }\end{array}$




$\begin{array}{llll}\text { im. } & \text { - imię } & \text { n. m. } & \text { - nazwa miejscowości } \\ \text { im. złoż. } & \text { imię złożone } & \text { pol. } & \text { - polski } \\ \text { jid. } & \text { - jidisz } & \text { prsł. } & \text { - prasłowiański } \\ \text { lit. } & \text { - litewski } & \text { tat. } & \text { - tatarski } \\ \text { muz. } & \text { - muzułmański } & \text { ukr. } & \text { - ukraiński } \\ \text { niem. } & \text { - niemiecki } & \text { wsł. } & \text { - wschodniosłowiański }\end{array}$

\section{Bibliografia}

Abramowicz Z., Antroponimia Żydów białostockich, Białystok 2010.

Abramowicz Z., Citko L., Dacewicz L., Słownika historycznych nazw osobowych Białostocczyzny (XV-XVII w.), t. I-II, Białystok 1997-1998.

Atlas gwar wschodniosłowiańskich Białostocczyzny (reedycja), t. 1, S. Glinka, A. Obrębska-Jabłońska, J. Siatkowski (red.), Warszawa 2014.

Barwiński M., Wpływ granic oraz uwarunkowań politycznych na zmiany struktury narodowościowej i wyznaniowej na przykładzie Podlasia, [w:] Czas i przestrzeń w naukach geograficznych. Wybrane problemy geografii historycznej, M. Kulesza (red.), Łódź 2008.

Barwiński M., Podlasie jako region pogranicza, „Studia z Geografii Politycznej i Historycznej" 2014, t. 3, s. 281-282.

Bogdanowicz E., Proces ksztattowania się nazewnictwa osobowego południowej Białostocczyzny, [w:] Studia Slawistyczne 2. Nazwy własne na pograniczach kulturowych, Z. Abramowicz, L. Dacewicz (red.), Białystok 2000, s. 21-28.

Bogdanowicz E., XVIII-wieczne nazewnictwo osobowe południowej Białostocczyzny, Białystok 2000 (wydruk komputerowy).

Bubak J., Kształtowanie się polskiego nazwiska mieszczańskiego i chłopskiego, Kraków 1986.

Citko L., Formacje hybrydalne w antroponimii polsko-białorusko-litewskiego pogranicza XVI wieku, [w:] Nazewnictwo pogranicza Polski, A. Belchnerowska, J. Ignatowicz-Skowrońska (red.), Szczecin 1999, s. 43-49.

Citko L., Nazewnictwo osobowe pótnocnego Podlasia w XVI w., Białystok 2001.

Dacewicz L., Nazwiska Tatarów w dawnym województwie podlaskim (XVI-XVIII w.), [w:] Nazewnictwo pogranicza Polski, A. Belchnerowska, J. Ignatowicz-Skowrońska (red.), Szczecin 1999, s. 63-68.

Dacewicz L., Hybrydyzacja nazewnictwa mniejszości narodowych jako zjawisko typowe na pograniczach etniczno-kulturowych, [w:] Onimizacja i apelatywizacja, Z. Abramowicz, E. Bogdanowicz (red.), Białystok 2006, s. 357-362.

Dacewicz L., Rola sufiksu -uk w kulturze nazewniczej Podlasia, [w:] Manuscula Linguistica in honorem Aleksandrae Cieślikowa oblata, K. Rymut, K. Skowronek, B. Czopek-Kopciuch, M. Malec (red.), Kraków 2006, s. 157-162.

Dacewicz L., Antroponimia Żydów Podlasia w XVI-XVIII wieku, Białystok 2008, s. 10-29. 
Dacewicz L., Historia nazwisk na kresach północno-wschodnich Rzeczpospolitej (XVIXVIII w.), Białystok 2014.

Dacewicz L., Podlasie $w$ badaniach onomastycznych $w$ przekroju historycznym - stan obecny, zadania $i$ potrzeby, "Studia Wschodniosłowiańskie" 2018, t. 18, s. 89-107.

Gala S., Produktywne typy antroponimiczne, "Rozprawy Komisji Językowej ŁTN”, t. XXXIV, 1978, s. 39-53.

Kaleta Z., Nazwisko w kulturze polskiej, Warszawa 1998.

Kaleta Z., Nazwisko w kulturze Słowian, "Język Polski” 1998, t. LXXVII 1-2, s. 29-38.

Maciszewski J., Społeczeństwo, [w:] Polska XVII wieku, Warszawa 1977.

Magda-Czekaj M., Wybrane typy słowotwórcze nazwisk okresu średniopolskiego w ujęciu historyczno-społecznym, Kraków 2011.

Małek A., Białystok pod zaborem pruskim 1795-1807, „Białostocczyzna” 1999, nr 4, s. 19-24.

Matuszewski J., Polskie nazwisko szlacheckie, Łódź 1975.

Mossakowska B., Nazwiska mieszkańców Komornictwa Olsztyńskiego, Gdańsk 1993.

Pisarkowa K., Konotacja semantyczna nazw narodowości, [w:] K. Pisarkowa, Z pragmatycznej stylistyki, semantyki $i$ historii języka. Wybór zagadnień, Kraków 1994, s. 215-234.

Rospond S., O nazwiskach na -ski, „Poradnik Językowy” 1966, nr 1, s. 1-12.

Rymut K., Nazwiska Polaków, Kraków 1999.

Sieradzki A., Poznańskie derywaty nazwiskowe XVI-XVIII wieku, Poznań 2013.

Tichoniuk B., Antroponimia południowej Białostocczyzny w XVI wieku, Opole 1988.

Wyrobisz A., Podlasie w Polsce przedrozbiorowej, [w:] Studia nad społeczeństwem i gospodarka Podlasia w XVI-XVIII wieku, A. Wyrobisz (red.), Warszawa 1981, s. $173-210$. 